\title{
Lymphoblastic Lymphoma with Primary Splenic Involvement and the Classic 14;18 Translocation
}

\author{
M. Gretel Carli, Antonio Cuneo, Nadia Piva, \\ Massimo Balboni, Franca Fagioli, Pierluigi Cavazzini, \\ and Gianluigi Castoldi
}

ABSTRACT: Clinicopathologic features of a case of lymphoblastic lymphoma (LyL) with the classic 14;18 translocation are described in this article. The patient had prominent splenomegaly with numerous splenic nodules, exhibiting a homogeneous blast cell infiltrate and occasional cells with cleft nuclei, a picture suggestive of high-grade non-Hodgkin lymphoma (NHL) possibly lymphoblastic. Early B-cell features were detected immunologically, thus confirming the diagnosis of LyL. The presence of primary splenic involvement and of the $t(14 ; 18)(q 32 ; q 21)$ are unusual in this histologic subset of B-cell NHL, these cytogenetic and clinicopathologic characteristics being typically associated with low-or intermediate-grade NHL of follicle center origin. These features, along with the presence of some centrocytelike cells in the biopsy sections, suggest that an unusual pattern of histologic evolution from a follicle center cell NHL may have occurred in this case of LyL.

\section{INTRODUCTION}

Lymphoblastic lymphoma (LyL) is a morphologically distinct entity of non-Hodgkin lymphoma (NHL) [1] with aggressive clinical behavior. Both T-cell and B-cell phenotypes have been documented, the former immunologic subset frequently involving the mediastinum, the latter presenting with prevalent abdominal disease [2]. Cytogenetic studies were performed in a limited number of patients, showing $14 q 11$ rearrangements and other less frequent abnormalities, besides normal karyotypes $[3,4]$. We recently observed a patient with typical B-cell LyL presenting with prominent splenomegaly and showing the classical $t(14 ; 18)(q 32 ; q 21)$ as the sole aberration. These unusual cytogenetic and clinicopathologic findings are here illustrated and discussed with regard to their possible significance in terms of origin and evolution of this rare form of NHL.

\section{CASE HISTORY}

The patient, a 71-year-old man, was referred to our institution with fever, weight loss, and splenomegaly-related symptoms. Physical examination was unremarkable, except for marked spleen enlargement. A chest $x$-ray film was normal. A computed

From the Chair of Hematology (M. G. C.. A. C., N. P., M. B., F. F., G. C.) and the Department of Pathology (P. C.). University of Ferrara, Italy.

Address reprint requests to: Dr. Antonio Cuneo, Department of Hematology. C.so Giovecca 203, 44100 Ferrara, Italy.

Received December 20, 1990; accepted March 18, 1991. 


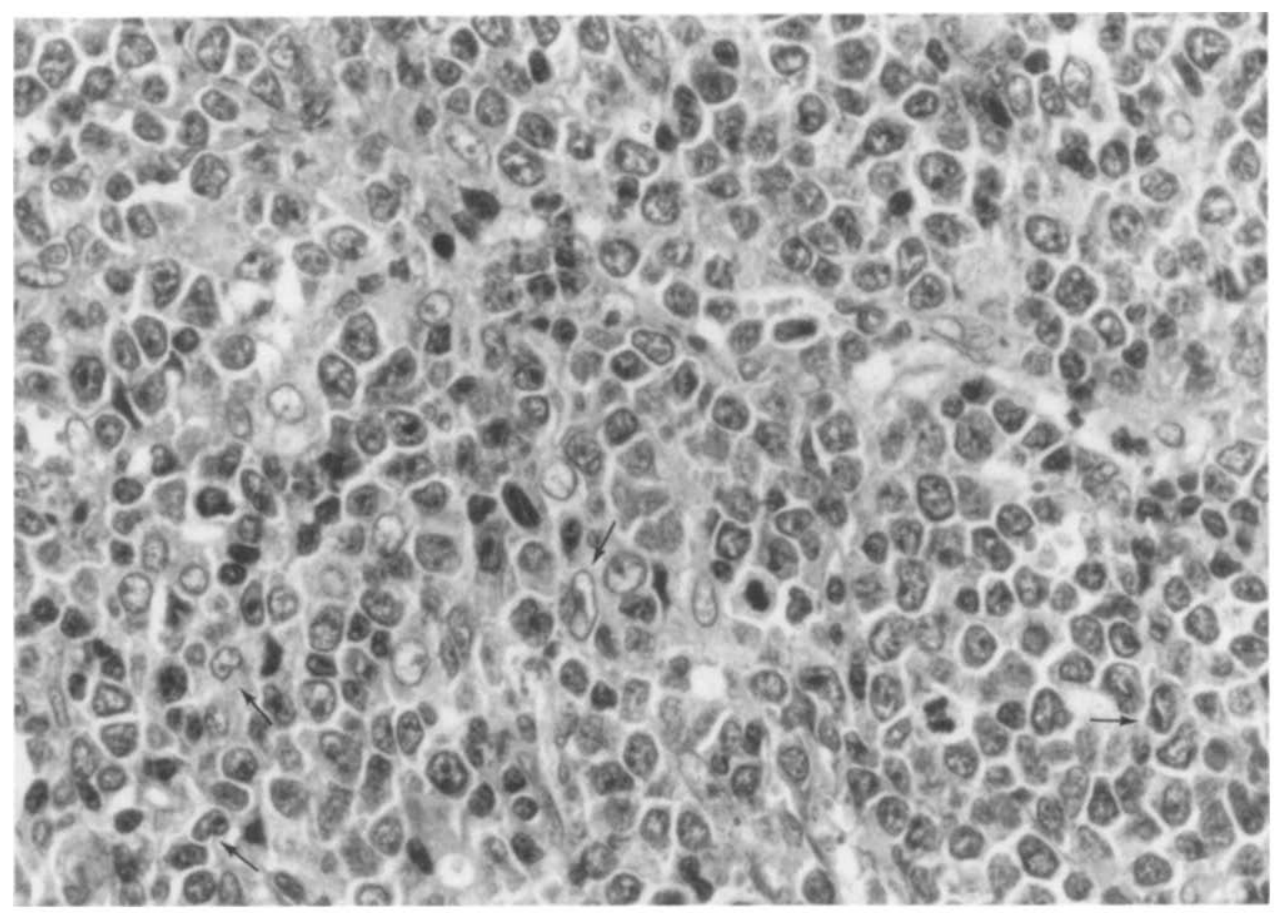

Figure 1 Histologic preparation showing diffuse infiltrate by lymphoblasts with some macrophages. Some cells with cleft nuclei are arrowed.

tomography (CT) scan of the abdomen revealed numerous splenic; nodules, one of which involved the ilium structures. At laparotomy, omental infiltration was documented, and multiple biopsies were obtained showing on frozen sections a monomorphic blast cell infiltrate, a picture suggestive of high-grade NHL. Bone marrow (BM) smears, as well as trephine biopsy sections, documented the absence of infiltration by lymphoma cells. Multiagent chemotherapy (cyclophosphamide, vincristine, daunorubicine, and prednisone) was administered monthly, and partial reduction of the spleen size was obtained. The patient is alive after 6 months, but his clinical condition has deteriorated (Karnowsky score, 60).

\section{MATERIALS AND METHODS}

\section{Histologic Studies}

A section of the biopsy specimen was sent to the pathologist for classification according to the Kiel system [5]. Histologic preparations were made from formalin-fixed material and were stained with hematoxylin-eosin, Giemsa, periodic acid-Schiff, and Gomori's silver impregnation.

\section{Immunophenotyping}

A piece of the diagnostic: tissue was minced into RPMI 1640 in sterile conditions immediately after surgical removal. An aliquot of the cell suspension, adjusted to the concentration of $1 \times 10^{6} / \mathrm{ml}$ was spun onto a cytocentrifuge, and slides were processed 
Table 1 Immunophenotype of neoplastic cells $^{a}$

\begin{tabular}{lc}
\hline $\begin{array}{l}\text { Monoclonal } \\
\text { antibody }\end{array}$ & \% Positive cells \\
\hline B4/CD19 & 92 \\
J5/CD10 & 87 \\
Ig & \\
Mu & Negative \\
Kappa & Negative \\
Lambda & Negative \\
TdT & 56 \\
C3bR/CD35 & 6 \\
Leu1/CD5 & Negative \\
OKT16/CD7 & Negative \\
Ki1/CD30 & Negative \\
OKT26a/CD25 & Negative \\
HPCA1/CD34 & 45 (weak) \\
\hline
\end{tabular}

${ }^{\circ}$ Determined by APAAP technique $(100$ cells observed on cytospin preparations). Results were confirmed by immunohistochemical stainings showing positivity for the L26 associated B-cell antibody, positivity in a slight minority of cells for the LN2 antibody and negativity for surface and cytoplasmic immunoglobulin chains.

according to the APAAP technique [6]. The expression of the following markers was tested: CD19, CD10, CD5, CD2, HLA-Dr, CD33, and surface and cytoplasmic immunoglobulins (Ig) (heavy and light chains).

Immunohistologic stains were also performed on paraffin sections with the following murine antibodies: UCHL 1 (CD45), L26 (detecting a pan-B cell antigen) (Dako), LN1, LN2, LN3 (detecting antigens associated with germinal center cells) (Biotest Diagn.) and anti-kappa, anti-lambda, anti-mu, anti-gamma and anti-alpha immunoglobulin chains. The presence of intracytoplasmic immunoglobulin chains on histologic sections was tested with the peroxidase-antiperoxidase method [7].

\section{Cytogenetic Analysis}

For cytogenetic analysis, $5 \times 10^{6}$ cells $/ \mathrm{ml}$ were cultured in RPMI 1640 additioned with $10 \%$ fetal calf serum (Gibco), and $50-\mathrm{ml}$ flasks were incubated at $37^{\circ} \mathrm{C}$ in $5 \% \mathrm{CO}_{2}$ humidified atmosphere. Cells were harvested according to standard procedures [8] after 24 hours.

\section{RESULTS}

The typical morphologic features of LyL [9] were observed on histologic sections. The cells had a fine chromatin pattern, and cytoplasm was scanty. Cleft nuclei were only observed occasionally (Fig. 1). As shown in Table 1, immunophenotype was that of a very immature B cell with negative cytoplasmic and surface Ig chains. Cytogenetically, the classical $t(14 ; 18)(q 21 ; q 32)$ was the sole aberration in $18 / 20$ metaphases (Fig. 2). Two cells had a normal karyotype.

\section{DISCUSSION}

In this reported patient, morphologic features and immunophenotype of neoplastic cells were typical of B-cell LyL [10]. Unlike previously reported cases, however, the clinical presentation was consistent with the occurrence of primary splenic involve- 


\section{on 16

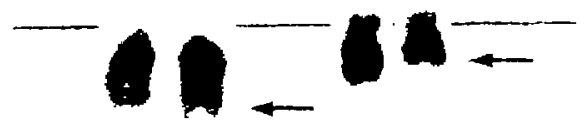

14

18

Figure 2 Partial karyotypes showing the classical $t(14: 18)\left(q 332 ; q^{21}\right)$ in our patient with Lyl. No additional clonal aberrations were detected in this patient.

ment. LyL with prominent splenomegaly has not been reported in the largest published series $[2,10,11]$, and the most frequent histological types encountered in primary splenic: NHL are represented by low-and intermediate-grade NHL, including follicle center cell lymphomas, intermediate lymphocytic lymphoma (included among the centrocytic type in the Kiel system), and small lymphorytic lymphoma $[12,13]$.

The presence of the $14 ; 18$ translocation as the sole aberration in our patient is remarkable, since previous studies have not detected this aberration in LyI. $[3,4,14\}$. However, some patients have recently been reported in which unusual evolution of low-grade follicle center cell NHL into high-grade Burkittlike histology were documented $[15,16]$. In one such case, immunophenotyping revealed, as in our patient, immature B-cell features, and cytogenetic analysis of BM lymphoma cells at the time of blastic conversion showed a $14: 18$ translocation variant as well as the classical $\mathrm{t}(8 ; 14)$.

While no residual nodular structures were observed in our biopsy sections, some cells had cleft nuclei, a feature suggestive of a possible follicle center cell origin. Thus, indirect evidence, based on the cytogenetic findings and on the clinical presentation, seems to suggest that histologic evolution from a follicle center cell lymphoma may have occurred in our patient during the preclinical phase of the disease [17]. Additional genetic events may be responsible for the clinicopathologic evolution of NHL with the $t(14 ; 18)$, irrespective of whether or not they may be detectable cytogenetically. Interestingly, the activation of c-myc by a complex cytogenetic rearrangement has recently been detected in a cell line established from a patient with Lyl lacking the classical 8:14 translocation [18]. Taken together, these observations possibly indicate that B-cell LyL may represent a histologic subset deriving in some cases from NHL of follicle center cell origin. Because current trends tend to unify treatment of LyL and of acute lymphoblastic leukemia [19], based on the notion that they may be similar clinicobiologic entities, the recognition of a disease subset of LyL possibly representing an evolutive form of follicle center cell NHL may crucial for the choice in such cases of a classical "antilymphoma" therapy.

This work was supported by MPI funds grants no. 90-40-06-005 and no. 90-60-06-018 (Rome). 


\section{REFERENCES}

1. Nathawani BN, Kim H, Rappaport H (1976): Malignant lymphoma, lymphoblastic. Cancer 38:964-983.

2. Mazza P, Bertini M, Macchi S, Lauria F, Pileri S, Rivano MT, Baccarani M, Ricci P, Fiacchini M, Vitolo U, Canta M, Paolino W, Zinzani PL, Poletti C, Verlicchi F, (;herlinzoni F, Tura $S$ (1986): Lymphoblastic lymphoma in adolescent and adults. Clinical. pathological and prognostic evaluation. Eur J Cancer Clin Oncol 22:1503-1510.

3. Koduru PRK, Filippa DA. Richardson MF, Jhanwar SC, Chaganti SR, Koziner B, Clarkson BD, lieberman PH, Chaganti RSK (1987): Cytogenetic: and histologic correlations in malignant lymphoma. Blood 69:97-102.

4. Fifth International Workshop on Chromosomes in Leukemia-Iymphoma (1987): Correlation of chromosome abnormalities with histologic and immunologic characteristics in non Hodgkin's lymphoma and adult T-cell leukemia-lymphoma. Blood 70:1554-1560.

5. Lennert K, Mori N, Stein H, Karserling E (1975): The histopathology of malignant lymphoma. Br J Haematol 31(Suppl):193-197.

6. Cordell JL, Falini B, Erber WN, Ghosh A, Abdulaziz Z, McDonald S, Pulfard KAF (1984): Immuno-enzymatic: labeling of monoclonal antibodies using immune complexes of alkaline phosphatase (APAAP complexes). J Histochem Cytochem 32:219-229.

7. Sternberger LA. Hardy PH jr, Cuculis J). Meyer HC; (1979). The unlabeled antibody enzyme method of immunocytochemistry. Preparations and properties of soluble antigen-antibodies complexes (horseradish peroxidase-antihorseradish peroxidase) and its use in the identification of spirochetes. I. Histochem Cytochem 18:315-333.

8. Sandberg AA (1980): The Chromosomes in Human Cancer and leukemia. Elsevier Science Publishing Co., New York.

9. Nathawani BN, Winberg CD, Rappaport H, Zelman RJ (1979): Lymphoblastic lymphomas: a clinicopathologic; study of 103 patients. Blood 54(suppl 1):531.

10. Cossman J. Chused TM, Fisher RI, Magrath I. Bollum F. Jaffe ES (1983): Diversity of immunological phenotypes of lymphoblastic lymphoma. Cancer Res 43:4486-4490.

11. Sheibani K. Nathwani BM, Winberg CI, Burke JS, Swartz WJ, Blayney D, van de Welde S, Hill LR, Rappaport H (1987): Antigenically defined subgroups of lymphoblastic lymphoma. Relationship to clinical presentation and biological behaviour. Cancer 60:183-190.

12. Kraemer BB. Osborne BM. Butler J/ (1984): Primary splenic presentation of malignant lymphoma and related disorders. A study of 49 cases. Canc:er 54:1606-1619.

13. Narang S, Wolf BC. Neiman RS (1985): Malignant lymphoma presenting with prominent splenomegaly. A clinicopathologic: study with special reference to intermediate cell lymphoma. Cancer 55:1948-1957.

14. Offitt K, Jhanwar S, Ebrahim SAD, Filippa D, Clarkson BD, Chaganti RSK (1989): $t(3 ; 22)(q 27 ; q 11)$ : a novel translocation associated with diffuse non Hodgkin's lymphoma. Blood 74:1876-1879.

15. Sham RL, Pradyumna P, Carignan J, Janas J, Olson JP (1989): Progression of follicular large cell lymphoma to Burkitt's lymphoma. Cancer 63:700-702.

16. Aventin A, Mecucci C, Guanyabens C, Brunet S, Soler J, Bordes R. Van Den Berghe H (1990): Variant $\mathrm{t}(2 ; 18)$ translocation in a Burkitt conversion of follicular lymphoma. Br J Haematol 75:367-369.

17. Cuneo A, Castoldi GI, Van Ien Berghe H (1991): Genomic alterations, origin and evolution of B-cell non Hodgkin's lymphoma (editorial). Haematologica 76:1-5

18. Kiem PH. Nourse J, Saltman DL. Blume KG. Cleary ML (1990): Concurrent activation of cmyc and inactivation of bcl-1 by chromosomal translocation in a lymphoblastic lymphoma cell line. Oncogene 5:1815-1819.

19. Hvizdala EV. Bernard C, Callihan T. (1988): Lymphoblastic lymphoma in children. $A$ randomized trial comparing LSA2-L2 with the A-COP' therapeutic regimen: A Pediatric Oncology Group study. J Clin Oncol 6:26-32. 